\title{
PARTICIPATORY PARITY AND \\ EPISTEMOLOGICAL ACCESS IN THE \\ EXTENDED CURRICULUM PROGRAMMES
}

\author{
James Windsor Garraway \\ Cape Peninsula University of Technology \\ garrawayj@cput.ac.za
}

\section{ABSTRACT}

The article examines students' engagement in university classrooms in South Africa. Of interest is the extent to which students experience some measure of parity of participation in these engagements. Such "participatory parity" broadly refers to students being able to act on a more or less equal footing with their peers and lecturers. Though much has been written about student engagement and its educational value, such engagement is not typically examined through Fraser's parity lens. Such parity matters because students are able to experience themselves as valued participants in the social world of the university. However, as what is being discussed is the university classroom, parity of participation in itself is not the only outcome, it is also gaining access to disciplinary knowledge through such participation, or what is referred to here as epistemological access. In order to examine the nexus between participatory parity and epistemological access a methodology for examining participation drawn from activity theory is mobilised. The paper then concludes with reflecting on the usefulness of using this theory and also the usefulness of promoting participatory parity in classroom engagement.

Keywords: participatory parity; epistemological access; activity theory

\section{INTRODUCTION}

The article examines classroom practices through the lens of social justice approaches, drawing on Fraser's justice dimensions of distribution, recognition and representation, and their combination under the heading of "participatory parity" (Fraser 1998). Fraser was not referring specifically to the university but rather to more broad participation in society. However, there has been a growing interest in mobilising her work to address injustices in higher education in South Africa (Bozalek and Boughey 2012; Leibowitz

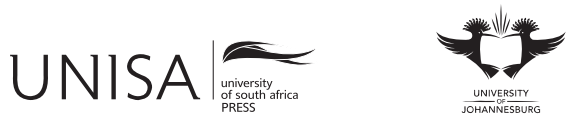

Education as Change

Volume 21 | Number 2 | 2017 | pp. 109-125

www.educationaschange.co.za

https://doi.org/10.17159/1947-9417/2017/2008 ISSN 1947-9417 (Online), ISSN 1682-3206 (Print)

(C) The Author(s) 2017 
and Boughey 2016). As the research deals with students' participation in the university classroom, it is also useful to mobilise Fricker's (2008) exploration of epistemic justice in social practices for two reasons: first, it focuses attention on knowledge and knowers and second it concerns communicative acts, both of which characterise classroom interactions.

Participation and so too participatory parity necessarily entail some form of student engagement in the classroom. Much has been written about student engagement in university studies, for example in tutorials (Kuh et al. 2008; Tinto 2006), and some of the main trends enabling/disabling successful engagement have been identified by Wimpenny and Savin-Baden (2013) and more locally in South Africa by Case (2007) .

In terms of what characterises engagement, there is a particular interest in South African education in access to university knowledge, as this has been and remains unequally distributed often along racial lines. Prior to the 1994 democratic transition South African universities were separated according to race and most resources were concentrated within the traditionally white universities. Very few black students attended these universities. Most attended "black universities," often far from the economic hubs and less well resourced. Post-1994 many universities were combined and access was opened to all potential students (Cooper 2015).

The sort of knowledge access put forward in university contexts is coined "epistemological access" (Morrow 2009) in South Africa. Enabling such epistemological access can in itself be understood as a social justice project as it involves the more equitable distribution of resources (Muller 2014). However, what may be missing in South African debates is how access may actually occur through student engagement with knowledge. What is then put forward is that promoting a social justice approach to engagement is not just beneficial in its own right but is also beneficial in promoting epistemological access. The particular dimension of social justice used in the analysis is "participatory parity" (Fraser 1998) supported through the additional perspective of “epistemic justice" (Fricker 2008).

\section{EPISTEMOLOGICAL ACCESS}

One of the main thrusts in higher education to achieve the goal of parity post-1994 is the overt teaching of so-called "powerful knowledge" (Young 2008, 14). It is powerful because it allows those who have it to engage on a more or less equal footing in discussions on the natural and social worlds, and so what they should or could be like. However, it is at the same time socially produced and thus always open to change as new entrants (for example, from the community) and information enters its sphere (Wheelahan 2010). Following from this is teaching for epistemological access, i.e. access to the ways of doing and thinking at the university in particular fields, as opposed to simply physical access (Morrow 2009) so that students are able to operate more confidently and independently. Consequently, Muller (2015) describes creating 
the conditions for epistemological access as having a strong social justice agenda within higher education.

Helping students to feel that they can participate and also setting up conditions where they have the means to do so are important in their own right as students experience the world as a more beneficial place. Students may then experience a sense of value and inclusivity. But as Fraser (1998) points out this sense of value and inclusivity is not in the sense of just anything goes - there are confines which suggest appropriateness. For example, claims related to creationism may have some purchase and be recognised as acceptable in religious debate, but have less purchase in scientific debate, in which scientific theory and evidence-based argument are paramount. Likewise, in the science classroom issues of recognition and hence a feeling of being able to participate on par with others, including with lecturers, is not open ended but requires some adherence to the field of science.

Muller (2015) attempts to pin down what might constitute epistemological access, and so too "powerful knowledge." Drawing on Winch (2010) his concern was that too much attention was paid to conceptual/abstract knowledge versus contextual practical knowledge, such that a third relational type of knowledge was ignored. He thus posits three types of knowledge in any field: epistemic knowledge, which is the disembodied or abstract knowledge of propositions, facts and theories typical of a field; practical knowledge, which is the knowledge of how to do things; and relational knowledge, which relates knowledge to practice. These three knowledge types are roughly equivalent to the Aristotelian divisions of episteme (pure knowledge), techne (practice) and phronesis or practical wisdom (though Muller does not draw this comparison). For Muller the knowledge which matters, the powerful knowledge of epistemological access, is relational knowledge. It is this knowledge that can combine propositions to understand and even change practices.

\section{PARTICIPATORY PARITY AND SOCIAL JUSTICE}

In presenting this article I draw on Fraser's (1998, 2009; Fraser and Honneth 2003) approach to enhancing social justice, which encompasses socio-economic, cultural and political dimensions that have effects on people's opportunities to thrive in society. In brief, these social justice dimensions are manifested through the extent to which there is an equal distribution of resources (distribution); on the cultural level, it entails the extent to which different social groups' ideas, opinions and interests are recognised (recognition); and at the political level (representation), it refers broadly to the right to make claims for social justice.

Distribution typically refers to large scale inequality such as between richer countries in North America and Europe and poorer countries in Africa, or between bosses and workers in capitalist society. Distributional justice has a particular racial flavour in South Africa where resources were unequally distributed in favour of the white 
population groups and manifestly to hold back black economic advancement. Though South African law was replete with discriminatory legislation, there is one item that stands out in respect of universities: the Extension of University Education Act, Act 45 of 1959 which made it illegal for black students to study at previously "open" universities without ministerial permission. As these open universities were the most resourced universities at the time, many black students were effectively excluded from participation and access to university knowledge.

Where unequal distribution is an issue then, one solution is often an economic one of redistribution of resources in an attempt to "abolish differences" (Fraser 1998, 10). At universities after the instantiation of democracy in 1994 this economic redistribution was in the form of enhanced access to bursaries for black students as well as open access for all students to universities. But this alone was not enough and consequently new structures of teaching and learning were introduced into universities: the foundation provisions. These were government funded interventions aimed at providing an extended and enriched degree programme for students who were previously disadvantaged (Scott, Yeld and Hendry 2007). There were thus attempts at redistributive justice within the university as well as in society more generally. However, this redistributive attempt has not been entirely successful with graduation still remaining strongly racially skewed (Cooper 2015). Being able to interact on an equal footing is regarded as particularly important for education in South Africa, where inequalities continue to plague the field of higher and other levels of education. The need to overcome our apartheid past in terms of the impact of racially exclusionary policies is an on-going battle.

The politics of recognition, or how recognition is typically enacted in society, involves more relational aspects in which peoples' favoured ideas and means of representation and communication may be undervalued by the dominant sectors of society. It refers, therefore, not to ad hoc attitudes or individual discourses but rather to "when institutions structure interactions according to cultural norms that impede parity of participation' (Fraser and Honneth 2003, 29). Those who currently suffer misrecognition in society can include minority groups such as the gay community or small ethnic groupings or other groups that have been historically disadvantaged and given less power in society, such as women. Included here would be larger ethnic groups which, although in the majority, may still suffer cultural disadvantage and misrecognition. In South African universities, it could be suggested that the experiences of black students may render them as misrecognised in the university. The solution to misrecognition is a "difference friendly world where assimilation to the majority is no longer the price of equal respect" (Fraser 1998, 7).

As Fraser $(1998,2003)$ reminds us, even though these dimensions can be separated for analytical purposes, they must necessarily be realised in a complementary way if the goal of social justice is to be achieved. This is evident, for example, in the case of foundation provision where justice in the form of redistribution-funding to enter university and so access to the resources on offer-is insufficient to allow for 
full participation in university activities, if what one brings to the university is not recognised. Combining the more objective distribution of resources and the more intersubjective recognition of difference can be understood through Fraser's (1998) concept of "participatory parity." In short this refers to groups and individuals being able to interact on an equal footing with others.

The more objective dimension of participatory parity, therefore, involves attention to the redistribution of wealth and opportunity which provides a platform on which people have the possibility of interacting more equally. The more subjective dimension involves those sorts of societal arrangements which permit difference and allow people's ideas and interests to be treated with equal respect such that they may experience equivalent representation and so be "recognised" (Fraser 1998, 2009). Although Fraser (1998) sometimes seems to assert a total equivalence in distribution and recognition she does acknowledge that, evidently, in capitalist society there will always be some level of economic disparity. Likewise, this understanding of parity does not propose that in the first year of university all knowledge is equal but rather that the university affords opportunity for interaction with some level of equal respect and equality.

In Fraser's (2009) later work she refers to a third dimension of social justice necessary for participatory parity - representation - in addition to distribution and recognition. This dimension occupies a more political space and refers to who is permitted or has the right to make claims of maldistribution or misrecognition, or who lacks "voice" through "wrongly denying some people the possibility of participating on par with others in social interactions" (Fraser 2009, 18). This is perhaps evident in the classroom where students do not, or cannot, imagine that their role is to bring forward new or original ideas because of political marginalisation. The use of representation as a form of analysis has been used in South Africa to examine on what basis students may challenge a lack of success or even exclusion from university (Bozalek and Boughey 2012).

Setting up conditions for parity of participation can be seen in two ways, as affirmative and/or transformative (Fraser 2003). It is possible, for example, to create cultural conditions in the classroom under which students' beliefs and values are "affirmed." This may then have beneficial outcomes for students in that they perceive themselves as valued and also successfully engage with the field of study. However, such an approach to affirmation can be limited to the particular and may not necessarily "disturb the underlying social conditions" which are responsible for misrecognition of cultural otherness (Fraser 2003, 74).

As has been already pointed out, the site of study is student engagement in the foundation provision classroom. One current approach to helping students gain access to university is to facilitate access to knowledge, and the research reported on here is interested in the intersection of engagement and knowledge. It would thus be useful to have some approach to social justice which pays attention to what people know and the interactions between them. I now turn to Fricker's $(2008,2013)$ work on social justice. 
Like Fraser, Fricker also highlights a more intersubjective dimension of social justice. Fricker $(2008,1)$ refers to this more intersubjective dimension as discriminatory epistemic justice which is in general "being wronged in one's capacity as a knower." This can be compared with Fraser's $(2003,29)$ recognition dimension which entails "cultural norms that impede parity of participation." Fricker's intersubjective dimension of justice is, to my mind, more focused than that of Fraser. Both philosophers can, however, be linked to intersubjective positions that highlight how disrespect may silence the voice of others as well as the value of recognising diversity.

Testimonial injustice (Fricker 2013,2008) refers to instances in which the speaker's discourse lacks credibility from the perspective of the hearer. For example, the lecturer may not hear or value student concerns, ideas and opinions, or even try to elicit them, as these are not viewed as credible. Testimonial injustice happens when the speaker experiences a "prejudicially deflated degree of credibility from the hearer" (Fricker 2013, 1319). The problem here for Fricker is twofold: not only is the other misunderstood, but knowledge that is useful and additive to the hearer's repertoire may be ignored. In the classroom context, therefore, the lecturer does not access what potentially important knowledge or even misunderstandings the students bring forward so that they can enlarge and even adjust their teaching, and students may therefore experience themselves as voiceless. This point has resonance with the sense that knowledge, even that enshrined in disciplines, is not inviolate and may change through contributions of the traditionally less powerful (Wheelahan 2010).

Second, Fricker's (2008) concept of hermeneutic injustice extends Fraser's social injustice argument. It refers to situations where students do not have the resources to properly make sense of experience nor to communicate this adequately to the hearer owing to the "unfairly impoverished interpretive resources she is working with" (2008, 70). For example, lecturers may present students with engaging discursive tasks so they may better learn complex concepts and so gain some measure of epistemic access, but students do not necessarily recognise this aim. Fraser $(2003,57)$ likewise makes mention of resource differentials, but more related to the politics of distribution: "not everyone enters these (societal) struggles on equal terms. On the contrary some lack the resources to participate on par with others, thanks to unjust economic arrangements." For Fricker (2013), one solution to this difficulty is through recognising that such lack of sense making is not the fault of the hearer, and adjusting accordingly.

Fraser (2009) alludes to various types of societal processes which may promote parity. When these are combined with Henschke's (2010) work on stimulating learning it is possible to extend Fraser's version of societal parity to parity in higher education. First, following Henschke, there is the establishment of an environment where students can feel free to ask questions, respond to peers and engage in intellectual thought experiments without being censored. Second, students should experience themselves as much as possible as equal partners in the production and distribution of knowledge (even though this may not always be feasible), through for example, being permitted 
and able to bring forward their own opinions and ideas. Providing the conditions for the production and distribution of knowledge, for example in open discussions, is a central issue for enabling participatory parity, and I would suggest, for gaining epistemological access. This position is supported by other authors. For example, Collis and Moonen (2001) describe how learning in the university IT classroom is significantly enhanced when students are given an opportunity to re-design processes and possible solutions.

\section{METHODOLOGY}

Fataar (2015) suggests that in applying social justice approaches to teaching and learning researchers should pay attention to what makes students want to learn, as well as to what and how they learn. This supports the use of the activity-orientated methodology discussed below.

Edwards (2016), coming from an activity perspective, characterises successful teaching and learning in the following ways. First, it is always dialogic between students and experts as well as between peers. Feedback from experts to students is essential here so that students may be guided towards the important knowledge of the discipline. But dialogicality is also more than this as it involves students in bringing forward their own ideas and knowledge and relating these to the disciplinary ideas. Thus students' knowledge is valued in activity perspectives, which is similar to Fricker's (2013) concept of testimonial justice. Second, as with creating conditions for hermeneutic justice, activity orientations to learning also place emphasis on students having the necessary learning tools to work with knowledge.

Whether we look at acquisition or different levels of participation as a means for learning, the degree to which students engage in activities may depend on whether they have the tools to work on the activities and also whether they perceive that there is some worth in their engagement. In activity theory terms this is the object-motive of the learning activity or what Edwards $(2015,23)$ refers to as "what matters" for the participants. Though the object-motive can be seen as an individual orientation to what is being learnt, it is also embedded within the sociality of the classroom, in students' interactions with their peers, and with the lecturers. As students try out new ways of thinking, or feel free to experiment with ideas, so learning and changing, they also begin to reshape the educational practices/activities they are engaged with. Students thus experience a change in agency as they try out and internalise new ways of understanding and sense themselves as becoming more competent in the field of study (Edwards 2016). This approach has obvious resonance with Fraser's concept of participatory parity and how it may be mobilised in the classroom through, for example, the allowance for the production of knowledge (Henschke 2010).

Data gathering was carried out using reflexive journal entries from the students in the class, once or twice per fortnight over a two month period. Using reflexive journals allows us to obtain rich data on students' experiences (Cousins 2009). Following the 
work of Edwards (2016), students were asked to record activities they undertook in class and actions they carried out where they felt safe to engage on a more or less equal footing with their lecturers, thus drawing directly on Fraser's (2009) understanding of social justice. Furthermore, they were asked to record what their aims and rationale were for engaging in these activities and actions. What matters (what is seen as worthwhile by students) effectively mediates between how and whether students engage with activities presented to them by staff (Edwards 2015). Incorporating more individual actions embedded within more significant collective activities, which are in turn pushed and pulled by an object/motive, links the method to activity theory analysis (Edwards 2015). It should also be pointed out that students were something of a captive audience as the journals were filled in in class time with their and their lecturers' consent. Doing the research in this way had two advantages. First, students could discuss their experiences with one another before putting pen to paper and second they could ask the researcher for clarity on what they should record in their journals.

Initially lecturers were also asked to reflect on where they thought they had promoted participatory parity using the same structure of activity, describing their actions and rationale as the students did. However, only one lecturer out of four, the HOD with whom the project was first negotiated, responded here. The reasons for not reporting were interestingly contradictory, as some lecturers suggested that they engaged with students all the time so there was no need to report on this, and others said that they did not do this at all during the reporting period, even though students reported on opportunities for engagement.

As the requirement of recording experiences may be quite challenging for first year students they were first taken through a case study example of an interactive, participatory class. The researcher then pointed out what would count as a description of the activity: the actions students took in doing the activity and the ways in which students reported on these actions in the case study reflected what mattered to them.

In analysing the data we are interested in the extent to which staff created opportunities for students to engage on an equivalent basis in the classroom, in other words when they were allowed to ask questions, give opinions, engage in discussion and so on. We are also interested in the extent to which these activities related to access to "powerful knowledge."

Analysis was first done through the lens of student engagement, following the useful categories described by Wimpenny and Savin-Baden (2013) in their synthesis of student engagement research. The paper synthesises students' experiences of engagement drawing from a number of selected papers, and identifies a number of trends in research, for example: engagement as the forming of multiple relations amongst students, between students and tutors and the careers they are aiming at (interrelational engagement); engagement as a process of changing agency in which students begin to experience themselves as more competent and self-sufficient in their fields of study; emotional engagement in which the primary pointers are student resilience and 
persistence; and engagement as sharing connections or disjunctions between students and others, often with strong undertones of social justice perceptions. This was really to categorise and reduce the data (Cousins 2009) so that trends which may give us some insight into issues of participatory parity may emerge.

\section{CONTEXT AND PROFILE OF THE STUDENTS}

The students and staff involved in this research project were all drawn from two classes in a first year applied science discipline, Food Technology, a discipline which, though practically orientated, also has a strong theoretical spine of physics, mathematics and microbiology. The research took place in a university of technology which offers courses closely aligned to vocations and which typically has lower entrance requirements than a more traditional university. The classes were small, comprising 27 and 26 students. These students were on a special support version of the regular programme, the extended foundation provision, in which they receive enriched teaching. This enriched teaching involves students spending more time on tasks, often with additional supporting content to the regular curriculum, as well as greater opportunity to interact with lecturers and tutors. The foundation provision is an attempt by government in South Africa to increase throughput of students who, for historical reasons and because of the current unequal distribution of educational resources, experience difficulty in coping with the academic project. The aim of foundation is thus to create conditions in which students can gain parity with their more educationally and socially advantaged peers.

\section{ANALYSING THE DATA}

In reading students' accounts of the participatory activities they engaged in, it was striking how many of these appeared to be more about procedural knowledge - how to do things - than about more relational characteristics of the field - propositions, concepts and their interrelatedness in practice. Some of the examples students gave were of science practicals (growing bacteria from their mouths, using scientific instruments to stain and view bacteria), doing physics and maths calculations in tutorials, learning how to use library search engines, comparing food labels for different descriptive elements, and so on. These sorts of comments (including the "fun" one below) may provide for some of the conditions where parity is made more possible. That being said, where students are allowed to participate, but not necessarily in terms of the powerful knowledge of the field they may be subjected to injustice. At first glance this could be because students are not being acknowledged as having valuable ideas, a case of misrecognition. However, it can also, perhaps better, be understood as students not being permitted to or given opportunity to engage around significant issues, so a case of misframing (Fraser 2009).

In addition, what was interesting was how students in some instances perceived these procedural activities as related to their professional field, for example: 
I really wanted to do it (stain and view bacteria), because I will encounter it daily in the profession I am pursuing.

Though this sort of engagement can be described as procedural, it also relates to the students' nascent sense of becoming in the field, what Billet (2009) describes as domainspecific procedural knowledge essential for a specific occupation. This would surely be a strong motive for students to participate in class, what Wimpenny and Savin-Baden (2013) refer to as inter-relational engagement through a connection of study to career.

A further point of interest is the contrast which emerges between students' perceptions of why they engage with procedural activities and the lecturer's underlying purpose. For example, in the bacterial growth experiments, students clearly enjoyed participating:

It was very interesting because a group of guys around me were just laughing at each other about the amount of "bacterios" they have. I wanted to do this because it was the first time I see the growth of bacteria. The lecturer made it sound so interesting, so I just had to do it. I also enjoy doing things.

But for the lecturer there was a different purpose, which is less about procedure and pleasure and more about attempting to make an epistemic point (in this particular instance the lecturer provided the researcher with a rationale for doing the activity):

The reason why I did this activity with the students was to demonstrate the importance of handwashing before and after a Microbiology practical; and also to demonstrate that bacteria are everywhere, and to demonstrate the difference between sanitation and sterilization - all concepts the students were introduced to during a formal lecture.

In terms of the actions students engaged with, these are mostly typical of classroom/ practical activity such as "... tried the question, explained to a friend and got the tutor to confirm it." A common participatory experience for students was a form of "show and tell" in which a student would be selected to present the solution to an equation in front of the class on the whiteboard. Students found this somewhat daunting but so long as they felt that they knew what they were doing the task was not too onerous:

We were given a physics problem on kinematics and asked to solve it individually. I felt so encouraged and happy to try it on my own without anyone's help. He first explained the chapter and gave a few examples on how to tackle the questions. I worked it out and he randomly selected pupils to work on the problem on the board. I was luckily chosen. I was so confident to take part in the activity, although I had a few hiccups. But I managed because the lecturer made me feel so safe. It interested me because we shared our own ways of understanding, and (also) seeing everyone participate in class.

As well as experiencing a "sharing of understandings" there is furthermore a sense of security provided by the lecturer. Students frequently talk of the ease they experience in accessing lecturers out of class or asking tutors questions in lectures ("we can ask them anything"). This was an experience shared by other students as they often perceived 
lecturers to be caring and creating safe spaces for interaction. Wimpenny and SavinBaden (2013) highlight the importance of what they term safe "psychosocial spaces," which can be strongly illustrated by this comment from a student:

My lecturers are the best, I won't lie. Lecturers answer questions and if you do not understand you can go to their office ... there is so much care at ECP .... Our lecturers are like mothers to us.

Though safety and security matter, perhaps as conditions under which parity may unfold, it is questionable whether these students were in fact acting on a more or less equivalent footing with their lecturer. Students may, perhaps, feel free to ask questions within clearly defined limits but less able to voice opinions, difference or new ideas which would be more characteristic of participatory parity.

Although there are illustrations of care and the creation of safe spaces, some students may experience learning through participation as "alienating" (Case 2007) or as something different to their own lifeworld that in a sense does injustice to them (Wimpenny and Savin-Baden 2013). Students thus talk of fear of being "shouted at," of being seen as stupid by their peers (particularly where the peers seem to have understood the task) or of not having the appropriate English to form an answer, which is likely to be the case where the medium of instruction (English) is not the first language of many of students:

I felt there is a barrier ... I fear being mocked by the class ... of answering stupidly. And:

I felt he needed to elaborate further, but I did not ask as I did not have confidence in my English.

Students experience injustice here in a number of ways. First, students indicate that what they may say may not be recognised by their classmates (and presumably their lecturers) as valid and acceptable; students are thus misrecognised (Fraser 1998). It can also be inferred that student do not see themselves as part of the group that is permitted to respond. In this sense, they are in Fraser's (2009) terms not experiencing the right to be represented at all; they are misframed.

In addition, the issue of the language gap can be seen as an example of a student not feeling they have the resources to raise issues in class, a form of "hermeneutic injustice" (Fricker 2013). As Fricker suggests, such injustice plays both ways: not only is the student not getting access to the knowledge they require, but the lecturer is unable to adapt and improve their teaching to suit their students.

Another comment that stood out for the researcher involved a student experiencing participation as something of an onerous task, foisted onto students against their will.

In their eyes we must interact everyday, even if we do not understand the answer.

Participation here is not something students do of their own volition. This raises questions about the autonomy of students in their participation. As Boughey (2008) 
describes, there are disciplinary university practices, and participation may be one of these, which are pretty much set out for students with limited opportunity to do things differently. However, it was notable that where students, even within this frame, could come up with a new approach, it was strongly motivating, for example:

He just wanted me to show him another way (to solve a problem) and he liked it because it was simpler than his and that made me happy.

This was one example out of four or five entries of the student making a contribution to the class, in this instance in relation to the lecturer.

The student experiences epistemic justice (Fricker 2013) as the knowledge he/she is bringing forward is valued on a more or less equivalent basis as that of the lecturer. In participatory parity terms, students experience themselves as acting on a more or less equal footing with their lecturers; they thus experience recognition (Fraser 2003). Students do not only experience making a contribution in relation to the lecturer, but also in changing the way things are happening within a set task, primarily between themselves and other students. Students talked of "noise," "tiffs" and that "some were even arguing!" indicating excitement in engagement, but also that different ideas were being raised from those initially presented by the lecturer, as the following quote outlines with reference to "straying":

The class was fun, there was lot of interaction between students and the lecturer and it was made fun by "straying" as we learnt new things ... the mood in which the lecturer presented the class was also very light and easy.

Such observations from students, in my view, are indicative of a more full participation in classroom activities; they are engaging in intellectual thought experiments without fear of censure (Henschke 2010). A further trend emerging from the student journals was that of engagement as working with difficulty, struggling and overcoming these difficulties, often at the individual level. Students here engage at an emotional level, particularly in having confidence about what they know:

We had this tutorial to do two days in advance, I had no idea, I was stuck. I was so angry. So I came with the tutorial undone in class. I asked the tutors (about the tutorial) and after their explanation I actually knew that I knew what was going on here. You can doubt yourself even if you know something. I started to believe myself and told myself "Margaret, you've got this and you can do this." Then I would write what I think is right, call the lecturer and find $90 \%$ of the stuff is correct. Most of the time I thought my questions were stupid but I was amazed when I asked the lecturer something, and I got the lecturer and the tutors thinking and I thought wow, every question is important.

Where the student refers to her realisation that "every question is important" she is intimating that what she has to ask is seen as valuable by the lecturer; she experiences recognition. In addition, as she is seen as "credible" she can be said to experience testimonial justice (Fricker 2013). Furthermore, the student talks of keeping going, 
even when this may be difficult. The importance of persistence has been highlighted in Barnett's (2007) work on students' will to learn, that learning at university often involves entering a realm of uncertainty, characterised by numerous possible pitfalls.

\section{CONCLUSIONS}

Foundation provision can lay claim to satisfying some of the conditions of distributive justice in that such provision attempts to set up the structures to provide access to university knowledge. What is less clear, and is one of the questions raised in this paper, is the extent to which this case of classroom practices may satisfy Fraser's other dimensions of social justice: recognition and representation.

Much has been written on student participation in higher education practice, often from the student perspective (Boughey 2008; Case 2007; Case, Marshal and Linder 2010; Wimpenny and Savin-Baden 2013), and how such participation enhances student learning (Tinto 2006). Viewing participation through a participatory parity lens (Fraser 2003) focuses attention on the sorts of enabling environments that allow students to exercise agency in classroom engagement. Fricker's (2013) account of epistemic injustice offers an additional lens in that engagement may not occur, not because lecturers do not create conducive environments, but because students do not have the resources to respond to these invitations; for example, where students report a lack of confidence in using English or perhaps where they simply do not know the field sufficiently well to hazard a guess.

Activity theory methodology was used to generate data and it would be useful to comment on how this methodology helped the paper make claims about participatory parity. Participants were asked to reflect on the overall classroom activity, the actions they performed in engaging with the activity and what drove them to engage (purpose). Using this approach contributed to understanding whether or not participatory parity was achieved in a number of ways. First, through asking students (and in one instance, staff) about an activity where they felt they could participate, we are able to ascertain the nature of the activity. What was found was that most of the activities students reported on were procedural, rather than concerned with helping students to tap into the core epistemic nature of the field. Bearing in mind Young's (2008) contribution that it is this powerful knowledge, rather than just procedural knowledge, which enables students to take greater control of their progress in the university, the current participatory teaching and learning initiatives are perhaps missing a significant learning opportunity. Through having their participation limited to these more peripheral activities students can be said to be subject to misframing (Fraser 2009).

As was pointed out in the one journal submission by a staff member, some form of access to powerful knowledge may, however, be the intention of the lecturer, but this is either not successfully communicated by the lecturer to the students, or the conceptual 
point is not recognised by students, possibly because they lack the resources to do so-a case of hermeneutic injustice (Fricker 2008).

Second, student actions in working on the classroom tasks reveal something about the tools that they bring to bear in order to participate, which are interesting in their own right. Students often talk of how helpful lecturers are and how they can ask them questions about the tasks they have been set. However, this may not be sufficient for parity of participation as students may feel free to ask questions but not free enough to engage more intellectually in thought experiments (Henschke 2010). In one extreme instance the student describes how the lecturers are like "mothers." This can be understood in Fraser's (2009) analysis of social injustice as an example of "misframing" in that some students' voices (for example, those on foundation) are marginalised. Those who are marginalised can then only "be supplicants for the benevolence of others" (Bozalek and Boughey 2012, 690), rather than being able to challenge the root causes which create this inequality, for example through contributing new ideas or processes.

In addition to the more normative participation tools such as asking and responding to questions there are also interesting tools used by students such as "arguing," "tiff(ing)" and "straying" in discussion, mostly with peers. These tools indicate a different order of engagement. Here students are not necessarily "supplicants" locked into the received university discourse but are beginning to bring forward potentially fresh ideas and ways of thinking. In Fraser's (1998) terms there is affirmation of students' ideas and interests, a case of recognition. Turning again to Fraser's (2009) work, these tools can be seen as "not just affirming" their positions in the university but possibly "transforming" them through their agency (Bozalek and Boughey 2012, 690). Furthermore, students are experiencing their own ideas and knowledge as credible and so are experiencing testimonial justice (Fricker 2013).

Third, the activity methodology reveals that participation works best where students understand the activity/task as both pleasurable and purposeful ("it is what I will be doing"). In Edwards's (2015) terms, students are engaged with what "matters" to them, whether this be because they are learning something new, something which interests them or something which connects them to a future career. From this perspective, creating an environment where students are working on what matters to them has the potential to enhance persistence and so to set some of the conditions under which participatory parity may occur. Better still, participatory parity can be further advanced if there is alignment between what matters in terms of epistemological access from lecturers' perspectives and what matters to students through some form of bridging pedagogy.

Getting information from both staff and students would be important in future research as it would highlight the extent to which staff and students have a common understanding of the object of the activity. There may be differences but what we would like to see is where there can be some common ground between them so that students 
are encouraged and feel able to engage rather than to simply comply with what staff tell them to do.

Participatory parity approaches to classroom participation can challenge more typical approaches to engagement in higher education or "the false higher education rhetoric of openness, access and inclusivity" (Wimpenny and Savin-Baden 2013, 325). They can furthermore, perhaps, open up spaces for enhancing "epistemological access" through allowing quality engagement with the powerful knowledge of the disciplines. Such quality engagement necessarily involves attention to Fraser's (2009) dimensions of recognition and representation. Furthermore, following Henschke's (2010) work, these dimensions can be realised where students are permitted to bring forward their own ideas and opinions in classroom discussions. When seen in this way participatory parity is not just an end in itself which enables students to experience learning in a more inclusive manner, but is also potentially a powerful pedagogical tool or boundary pedagogy to enable access to disciplinary knowledge. As has been outlined, this is currently an important issue in South African higher education. Boundary pedagogies are interesting in their own right as they are situated between what students bring from their experiences and the more formal knowledge of the disciplines. They therefore promote at least the partial hybridisation of outside student knowledge and inside (the university) disciplinary knowledge (Cooper and Ralphs 2016), concomitantly developing and promoting student agency.

\section{REFERENCES}

Barnett, R. 2007. A Will to Learn: Being a Student in an Age of Uncertainty. Maidenhead: McGraw Hill.

Billet, S. 2009. "Realising the Educational Worth of Integrating Work Experiences in Higher Education." Studies in Higher Education 34 (7): 827-43. https://doi.org/10.1080/03075070802706561

Bozalek, V., and C. Boughey. 2012. "(Mis)framing Higher Education in South Africa.” Social Policy and Administration 46 (6): 688-703. https://doi.org/10.1111/j.1467-9515.2012.00863.x

Boughey, C. 2002. "From Equity to Efficiency: Access to Higher Education in South Africa." Arts and Humanities in Higher Education 21 (1): 65-71.

Boughey, C. 2008. "Texts, Practices and Student Learning: A View from the South.” International Journal of Educational Research 47 (3): 192-99. https://doi.org/10.1016/j.ijer.2008.01.007

Case, J. 2007. “Alienation and Engagement: Exploring Students' Experiences of Studying Engineering." Teaching in Higher Education 12 (1): 119-33. https://doi.org/10.1080/13562510601102354

Case, J., D. Marshall, and C. J. Linder. 2010. "Being a Student Again: A Narrative Study of a Teacher's Experience." Teaching in Higher Education 15 (4): 423-33. https://doi. org/10.1080/13562510903560028 
Collis, B., and J. Moonen. 2001. Flexible Learning in a Digital World. London: Kogan Page.

Cooper, D. 2015. "Social Justice and South African University Student Enrolment Data by 'Race', 1998 2012: From 'Skewed Revolution' to 'Stalled Revolution.” Higher Education Quarterly 69 (3): 237 62. https://doi.org/10.1111/hequ.12074

Cooper, L., and A. Ralphs. 2016. RPL as a Specialised Pedagogy: Crossing the Lines. Pretoria: HSRC Press.

Edwards, A. 2015. "A Tool for Public Services Research and Development." International Journal of Public Leadership 11 (1): 21-33. https://doi.org/10.1108/IJPL-11-2014-0019

Edwards, A. 2016. "Cultural-Historical Approaches to Teaching and Learning in Higher Education; Teaching to Support Student Agency." In Theorising Learning to Teach in Higher Education, edited by B. Leibowitz, V. Bozalek and P. Kahn, 124-37. London: Routledge.

Cousins, G. 2009. Researching Learning in Higher Education. New York: Routledge.

Fataar, A. 2015. Engaging Schooling Subjectivities across Post-Apartheid Urban Spaces. Stellenbosch: Sun Media. https://doi.org/10.18820/9781920689834

Fraser, N. 1998. "Social Justice in the Age of Identity Politics: Redistribution, Recognition, and Participation." Paper presented at the Tanner Lectures on Human Values, Stanford University, April 30-May 2.

Fraser, N. 2009. Scales of Justice. Reimagining Political Space in a Globalizing World. New York: Columbia University Press.

Fraser, N., and A. Honneth. 2003. Redistribution or Recognition? London: Verso. https://doi. org/10.1002/9780470756119.ch54

Fricker, M. 2008. "Epistemic Injustice: Power and the Ethics of Knowing.” Theoria 61: 69-71.

Fricker, M. 2013. “Epistemic Justice as a Condition of Political Freedom?” Synthese 190 (7): 1317-332. https://doi.org/10.1007/s11229-012-0227-3

Henschke, J. A. 2010. "Bringing Together Personal Learning, Higher Education Institutional Elements towards Support for a Re-Orientation toward a Focus on Lifelong Learning and Education." In Encyclopedia for Using Technology in Adult and Career Education, edited by V. Wang. Hershey: IGI Global.

Kuh, G., T. Cruce, R. Shoup, J. Kinzie, and R. Gonyea. 2008. "Unmasking the Effects of Student Engagement on First Year College Grades and Persistence." Journal of Higher Education 79 (5): 540-63. https:// doi.org/10.1353/jhe.0.0019

Morrow, W. 2009. Bounds of Democracy: Epistemological Access in Higher Education. Cape Town: HSRC Press.

Muller, J. 2014. "Every Picture Tells a Story: Epistemological Access and Knowledge." Education as Change 18 (2): 252-69. https://doi.org/10.1080/16823206.2014.932256 
Ryle, G. 1949. The Concept of Mind. London: Hutchinson.

Scott, I., N. Yeld, and J. Hendry. 2007. Higher Education Monitor No. 6: A Case for Improving Teaching and Learning in South African Higher Education. Pretoria: Council on Higher Education.

Tinto, V. 2006. "Research and Practice of Student Retention: What Next?" Journal of College Student Retention: Research Theory and Practice 8 (1): 1-19. https://doi.org/10.2190/4YNU-4TMB-22DJAN4W

Wheelahan, L. 2010. Why Knowledge Matters in the Curriculum: A Social Realist Argument. New York: Routledge.

Wimpenny, K., and M. Savin-Baden. 2013. "Alienation, Agency and Authenticity: A Synthesis of the Literature on Student Engagement." Teaching in Higher Education 18 (3): 311-26. https://doi.org/10 $.1080 / 13562517.2012 .725223$

Winch, C. 2010. Dimensions of Expertise. London: Continuum.

Young, M. 2000. Bringing Knowledge Back In: From Social Constructivism to Social Realism in the Sociology of Education. London: Routledge. 